Wojciech E. Zieliński

University of Gdańsk

Faculty of Social Sciences

Institute of Philosophy, Sociology and Journalism

e-mail: wojziel@ug.edu.pl

\title{
A few remarks on the axiology of university work*
}

\begin{abstract}
This article is a reflection on selected aspects of the axiology of work at a university. It consists of three parts. In the first one, the author considers the problem of uncertainty of knowledge, a typical state in science at the turn of the $20^{\text {th }}$ into the 21 st century. This is followed by an attempt at analysing its influence upon the quality of university activities.

The second part concentrates on a special form of education-distance learning, which seems to result in increasing discrepancy between the content of the transmitted message and the moral situation of its recipient, especially in the field of humanities.

In the third and last part, the author discusses the need for axiological transmission of ideas and the moral responsibility of an academic teacher.

In these deliberations, the author refers to the works of the historian of science, e.g. Dolby, the philosophers and historians of the society such as Habermas, Popper, Znaniecki and Ossowski, and the theologian, Newman.
\end{abstract}

Keywords: axiology, ideas, knowledge

JEL Classification: A20, Z1

\footnotetext{
* The article is an updated version of the paper published in Polish in the Annales. Ethics in Economic Life, 9(2), 37-46.
} 


\section{Introduction}

The article is a reflection on selected aspects of the axiology of work at a university and is divided into three parts. The first part addresses the problem of uncertain knowledge, a characteristic state of science at the turn of the $20^{\text {th }}$ into the $21^{\text {st }}$ century. Next, the issue is analysed with respect to its influence on the quality of university work. The second part focuses on a special form of education-distance learning, which seems to result in an increasing discrepancy between the content of the transmitted message and the moral situation of its recipient, especially in the field of humanities. In the third part, the author dis-cusses the need of axiological transfer of ideas and the moral responsibility for it on the part of an academic teacher.

A humanistic approach - objective towards the subject matter and metaobjective towards disciplines that deal with it - is to be seen not only as biographical outcome of author's academic output, but above all as a standpoint that he treats axiologically, as important and desirable in the present state of social affairs and in the present state of sciences that cover these matters. Exposing the above assumptions regarding the investigated subject area and used materials, as well as the method of approaching them, seems to be important as it is through revealing the limitations of what will be said that the critique of such statement can become more precise; and critique - practiced in a falsificationist spirit of critical rationalism - is treated here as the proper way of getting closer to the truth.

\section{The problem of uncertain knowledge}

One of contemporary authors, Alex Dolby - a historian of science from the Centre for History and Cultural Studies of Science at the University of Kent-writes: While in the mid-twentieth century science "might have been an autonomous intellectual activity, conducted within its own special institutions," today it seems to remain solely an inherent component of economic life. After all, everyone appeals to its image-from cream sellers to those who want to legalize new professions. [Thus] "we are in danger of losing our vision of science in the glare of its many reflections," concludes the historian (cf. Dolby, 1998, p. 13). What is more, there is a threat that we will lose sight of axiology, of ethics of academic work, of university work, if we marvel at the blinding and expansive, though doubtful in quality, the glare of free-market principles of attracting attention and valuation.

The distinctive features of science-explains Dolby (1998, p. 210)—are relative to its changing institutional form. In other words, the significance of institutional methods means that what is considered science depends, to some extent, in its social context. This context, as mentioned before, is nowadays largely shaped by the free economic and cultural market. And even though "modern science seems to attract (or expose) really flamboyant charlatans in areas that attract very 
generous research fundings" (1998, p. 265), it might be true about all areas of study that new people flowing into science-especially young people who are hungry for success - "have much to gain by challenging old dogmas" (1998, p. 278), most likely also those "dogmas" that relate to the former indicators of axiological quality of university work. Is the quality of new solutions undeniably higher than the quality of the old ones? Does asking this question and giving a possible answer to it-not to mention exposing the matter it refers to-touches on the issue of the uncertainty of knowledge?

Science is uncertain knowledge - asserts the cited author.

It is no longer plausible to say that current scientific understanding represents reality directly, rather it is an approximate working representation of the reality we hope to know more fully in the future. Science is, therefore, a form of working knowledge. In the process of knowledge construction, new ideas are embedded in the shared meanings of local forms of life. Only as the intellectual ferment of knowledge creation dies down and the initial features of the local context are suppressed, do more widely shared scientific meanings emerge. While knowledge remains in flux, its connection to context is at its most apparent. (Dolby, 1998, p. 17)

If the above comments are deemed valid, we can reach a conclusion that the meta-objective axiological activity undertaken by the people of science while creating this working knowledge is meaningful for science itself as well as for social life. It is not without significance not only for the content of social experience and for the content of science, but also for the form of their mutual communicative exchange. However, as Dolby observes,

many scientists judge it prudent to exaggerate their displays of competence. They use the most complex equipment they can gain access to, they use the most difficult technical arguments, they pack their communications with unnecessary jargon, and they cite far more predecessors than they need (being keenly aware of who should not be cited as well as who should). Such diligence in the use of existing knowledge is a result of the way the institutional pressures work. A little less technical complexity, a little less jargon, and a little less concern with honouring intellectual ancestors would do science no harm. (1998, p. 175)

It should be added that such "celebration" plays a part in shaping the social image of science and, indirectly, in shaping the quality of social life. On the one hand, it raises a question of what is true and what is only an appearance, a facade of these "displays of scientific showmanship" - the level of knowledge uncertainty seems to increase; on the other hand, it impacts the social relations between those (e.g. academic teachers) who, through their work, influence the knowledge and behavior of others, and those (e.g. students) who still seek to exert such influence. It is especially evident in social sciences. 
My own view of social science - continues Dolby (1998, p. 207)—is that it is best regarded as a form of critical thinking. To the extent that it is concerned with precise facts, these are historical facts (that is, about the past, both recent and remote). Factual claims about the present and future are inextricably tied to questions of value. Therefore, social science is as much philosophical and historical as it is scientific.

According to the cited author, social sciences may, "in the best case, provide tools for critical thinking about social issues". While using academic strategies to create and reproduce knowledge "we simplify natural phenomena"; with "humanistic phenomena" happens "something totally opposite": here people "make use" of newly created conceptual tools and strategies, or the procedures for exposing them, and thus complicate "social interactions" (Dolby, 1998, p. 214). We all know that the degree of complexity of social interactions in which we participate daily has an influence on how we experience the quality of social life.

In the light of the foregoing remarks on the broadly understood uncertainty of knowledge, we should follow Dolby's advice and consider that perhaps "we should not place too much faith in the present form of science." After all, science does not have fixed properties - "by changing society, it changes its own nature." And "would not we be better off with a new kind of science which gives us more of what we want with fewer problems?" And if so, is it possible to change this science that responds to market demands for the better? (Dolby, 1998, p. 12).

Well, it seems - and this is a note integrally related to the content of this article - that one of the ways to change science for the better is to restore the moral rigours of practicing it, like those mentioned by the previously quoted Ossowski, independently of the current, systemic and social conditioning of its functioning, and perhaps even to restore these rigors against the current conditioning. Nonetheless, it requires adopting a bold and consistent stance of the non-conformist workers of science themselves, ready to shape the culture of their work in the light of ideas, challenging the norms of the current economic situation; also, at the expense of recognition, which is granted according to these norms.

When it comes to the educational dimension of modern science- the exposition of which will take us to the next part of the article for a moment-it appears that one of the ways to make science better is through bringing back the element of directness in the teacher-student relation; in other words, restoring this moral component of the educational relationship, which nowadays, with highly technologized forms of education, does not seem to be indispensable, but which at the same time - if we have second thoughts regarding the above-will not be present if we resort solely to technology. Here again, the central role is performed by specific people - people of science, academic teachers, because it is up to them to take the first moral step towards those at whom their work is targeted. Strictly speaking, the point is not to put unnecessary distance between a teacher and a student, not to cordon oneself off from students with a computer, an overhead projector, own notes, erudition or declaration of limited competences, etc., especially when the student expects from the teacher something more than just professional knowledge (and it seems that sometimes students expect something more 
indeed). This undesirable distance may lead to a situation in which an important question will not be asked, and that an attempt to answer it will not be made. And let us presume that this will not be beneficial to any of the parties. After all, social coexistence, an agreement in important matters - something we do not experience in excess nowadays - makes use of the achievements of specialized scientific disciplines, but these achievements cannot be put into use without people who are morally capable of their communicative exchange.

\section{A specific form of distance learning}

When Iochannes Lochman, Rector of the University of Basel, was inaugurating the institution in 1459 , he reportedly said:

The university cannot be satisfied with producing professional experts. The university must become a community of the people who search for the meaning of life. It must become "officina humanitatis", i.e. a "workshop of humanity," otherwise it will bring humanity more harm than good. (cited after Seweryński, 2004, p. 13)

In the preface to the series of nine lectures delivered in 1852 during the attempts to establish the university, the philosopher and theologian, John Henry Newman, a prominent figure of Victorian England, the first Rector of the Catholic University in Dublin, adopted the following concept:

place of teaching universal knowledge. This implies that its object is, on the one hand, intellectual, not moral; and, on the other, that it is the diffusion and extension of knowledge rather than the advancement. If its object were scientific and philosophical discovery, I do not see why a University should have students; if religious training, I do not see how it can be the seat of literature and science. (Newman, 1990, p. 79)

These two, randomly selected from the history of science and higher education, demonstrate the ongoing and long-lived dispute over the concept of the university and the character of its social role. Today, the topic of this dispute is increasingly subject to the economic rules of the market and a source of endless worries for the advocates of its classical form. Our focus, however, is not the vast problems associated with the concept of the university, but on its aspecteducation itself, which remains inherently related to universities.

Newman's lectures are not recalled here by coincidence, and it was no coincidence that the market is mentioned. Newman belongs to those philosophersand the author of this article holds them in high esteem - who defend an ordinary person, "with an average mind and incomplete education against the educated specialists" (cf. Mroczkowski, 1990, p. 27). Today these ordinary persons - on the street, shops and offices, in classrooms and university lecture rooms-are 
probably as numerous as they used to be, but now-maybe even more than before - they are subject to social, or rather institutional exclusion. What makes this phenomenon even worse, if it really occurs, is that who takes part in this exclusion of ordinary people from deciding on the shape of structures and systems in which they, also out of necessity, function - so from making decisions on matters important to these persons as well-are many representatives of science. Differentiate or die!- - says one of the key principles of modern marketing (cf. Trout \& Rivkin, 2000). Yet, it is no longer simply a business management principle, but what seems to be a moral principle that is applied at a university and in an ordinary school, at increasingly earlier stages of education. While it constitutes an element of the actual state of educational affairs, it remains the subject of, for instance, sociological description. And since it is treated normatively, systemically, as a moral principle of acting practically, then it is justly subject to the analysis of an ethicist.

Today, as some people suggest, "we were told that we can be anyone we want." But in fact - it is evidenced by the common experience of an ordinary person and the practical experience does not seem to be less valid than a scientific evidence - not everyone can become anyone they want, but they also do not have to. Hence, an academic is torn between the requirements of (a) the market that expects mobile, comprehensively educated university graduates, capable of winning the race for high-paying jobs, and (b) one's own axiology, one may wonder whether the academic path one has chosen may require a humanizing adjustment and if it would be favoured by the systemic conditions of one's work. A critical reflection on making such an adjustment may serve to reduce the mentioned distance - the space between the desired and the actual face of university work. All the same, the reflections should begin with the knowns. The academic teachers, through their professional and social experiences, are aware of a substantial discrepancy between (a) the scientific level and complexity of accumulated knowledge about social relations and (b) the moral quality of these relations in their practical dimension. Ignoring these experiences and walling oneself off in the maze of science "celebrated" for its own sake while disregarding the metaobjective axiological self-reflection on its social impact does not reside well with philosophical wisdom.

\section{The need for axiological transmission of ideas}

The postulates of scientific responsibility, quoted in the introduction to the problem of uncertain knowledge at its present stage, were formulated by Stanisław Ossowski several decades ago. Yet, they are not to be treated here as sentimental notes from the past, memories from the time when the world - also the world of science - was, or only seemed, better than it is today, in a sense. Quite the opposite. By recalling these postulates, the author would like to underline the conviction that the quality of social world, and thus the quality of its scientific sphere as 
well, is a derivative of the broadly understood quality of its creators - the participants of communication activities, the acting people, creating social unions and organizations, social places and spaces. It can be said that communication activity - at the present stage of human development - is a constitutive element of the social world. There is no society without communication activities. But "a critical communication activity" [WZ] is not its constitutive component in the sense specified above. The social world can exist and, in many places, exists without critical communication activity. It exists in totalitarian systems, where criticism of the system is, by definition, out of question; it exists in those socio-organizational systems in which the unquestionable dogma of political correctness seems to be a golden calf, made out of the unreason of the participants in the activity; it exists in a family in which parents do not have time to listen to what children have to say, etc. A social world devoid of critical communication activity materializes also in the lecture room when lecturer conducts the liturgy of knowledge, in awe of own erudition, or when he or she declaims on topics unrelated to the lecture, or from a yellowed piece of paper, rattles off rules that were not updated for years.

Nowadays, the university students do not expect displays of showmanship of idols, who say only what the mass audience expects. And not everyone expects to go about their studies the easy way, thanks to a lack of requirements or the mechanical repetition of didactic activities. But, besides the expectation of a reliable transmission of professional knowledge, what is not less important or less factual is probably the expectation of a reliable transmission of moral attitude by the one who teaches knowledge. And of course, it is not about the superficial nobility of the lecturer, but about his or her moral authenticity, which includes imperfections, whose skillful didactic use cannot only prove valuable at the object level but maybe be also significant in the moral space.

If less than imperfect people are to be found on both sides of a lecture room, and if, that among various social deficits, there is a palpable deficit in ordinary moral closeness between people of the modern society, then, perhaps the lecture room should be turned into a place of moral (self-)education of its users. Surely, for objective reasons, it is easier to obtain such a component during lectures from the field of humanities; yet, numerous and many a time tragic experiences reveal that the moral component of didactic activities is not insignificant in any place. The responsibility for such an occurrence rests with the teacher, and not the student. It is the teacher who has a microphone and so, has the power and has the courage - or maybe lacks the courage - not to become a man without qualities; in the likeness of those who make a good impression, but are a spitting image of each other, of fruits from the market, of union bureaucrats, formatted by the law.

The postulated critical communication activity is a component of ethics, including the ethics of science and teaching. Ethics always begins here and now, with axiological decisions of its users - the critical participants of the communication activity. Those who are truly devoted to the application of ethics in its personal, philosophical and practical dimension-irrespective of their profession and social status - always here and now, face old and young questions about values and norms as well as the ideas that are subject to the critical analysis and have 
possible application in solving current problems. The current problem lies in the characteristic uncertainty of a modern person's knowledge and the related methodological and axiological condition of science. The current problem lies in distance learning, understood as an educational activity that is morally torn. The current problem lies in the vagueness of the ideas that create this activity.

\section{Conclusions}

The above remarks were made in the belief that the work at a university and all other manifestations of human activity, inevitably entails making axiological decisions by those who have dedicated themselves to such. These decisions accompany the content and the formal aspects of scientific-didactic activity as well as its objective and meta-objective level. Science, however, is not free from defects that are found in the social experiences. Nowadays, a certain type of conformism in science seems to consist in the fact that people of science are withdrawing the meta-objective axiological decisions regarding the system in which they function, and the forms of their own work - in the name of respecting individual freedom, political correctness, and market demands. Even though individuals are not to blame for flaws in the system that manages them, it is quite impossible to absolve those individuals, in a reasonable way, from responsibility for shaping this system. After all, social systems are built with the participation of people. Thus, if the opportunistic ideology of the market in the university work mainly translates into developing students' abilities to compete, disregarding their own race, history, and ingrown values, etc.; if graduates of a university leave its halls saturated with knowledge, skills, and abilities, but with scarcity of ideas because during a few years of education they were trained only to recognize market demands; and if all involved parties have doubts as to whether acting this way is proper, the needs for their axiological decisions is all too clear.

Being committed to university work - just as in the case of any other work done with passion - is not only about the feeling that what you do, you do well, but also that you do something good. And it is not just about having this feeling but, above all, about actually doing it. Even if these words sound like naive clichés, so be it. In ethics - the ethics of science and teaching included - one must, in a sense, keep starting over.

\section{References}

Aristotle. (1996). Etyka Nikomachejska [Nicomachean Ethics]. In Dzieła wszystkie (Vol. 5). Warszawa: Wydawnictwo Naukowe PWN.

Dolby, R. G. A. (1998). Niepewność wiedzy. Obraz nauki w końcu XX wieku. Warszawa: AMBER. 
Mroczkowski, P. (1990). Przedmowa thumacza. In J. H. Newman, Idea uniwersytetu. Warszawa: Państwowe Wydawnictwo Naukowe.

Newman, J. H. (1990). Idea uniwersytetu. Warszawa: Państwowe Wydawnictwo Naukowe.

Ossowska, M. (1986). Sociology of morality. Zarys zagadnień. Warszawa: Państwowe Wydawnictwo Naukowe.

Ossowski, S. (2001). O osobliwościach nauk społecznych. Warszawa: Wydawnictwo Naukowe PWN.

Seweryński, M. (2004). Uwagi o problemach etycznych środowiska akademickiego [Remarks concerning ethical problems of the academics]. Annales. Ethics in Economic Life, 7(2), 11-21.

Trout, J., \& Rivkin, S. (2000). Wyróżniaj się lub zgiń. Jak przetrwać w erze morderczej konkurencji. Kraków: IFC Press.

Watkins, J. W. N. (2001). Wyjaśnianie historii. Indywidualizm metodologiczny i teoria decyzji $w$ naukach społecznych. Wrocław: Wydawnictwo Uniwersytetu Wrocławskiego.

Zieliński, W. (2006). Kilka uwag o aksjologii pracy uniwersyteckiej. Annales. Ethics in Economic Life, 9(2), 37-46. 